\title{
Digital Bridge or Digital Divide? A Case Study Review of the Implementation of the 'Computers for Pupils Programme' in a Birmingham Secondary School
}

\author{
Jonathan Padraig Morris \\ King Edward VI Sheldon Heath Academy, \\ Birmingham, UK
}

jmorris@keshacademy.com

Executive Summary

Attempts to bridge the Digital Divide have seen vast investment in Information Communication Technology in schools. In the United Kingdom, the Computers for Pupils initiative has invested $£ 60$ million of funds to help some of the most disadvantaged secondary school pupils by putting a computer in their home.

This paper charts and evaluates the implementation of the Computers for Pupils programme and its extension, the Universal Home Access programme, in a Birmingham secondary school. This case study employs a complementary mixed-method approach - the questionnaire method with a year 9 cohort of pupils and interviews with their ICT teachers.

Findings from this research, which are divided into four themes-laptop use and support, provision of connectivity, decisions on software and hardware, and technical support and repairfound several issues with the implementation of the programme. As a consequence, several recommendations for improvement are offered, all aimed at the more effective implementation of the national Home Access programme, which has recently begun its implementation across England.

Keywords: Digital Divide, Home Access, Secondary Education, ICT

\section{Introduction}

\section{The Divide}

The Stevenson (1997) report claimed that the educational benefits of Information and Communication Technology (ICT) has been so widely and so firmly recognised that it is clear pupils will be significantly disadvantaged without full access to such in their schools. This is a bold claim.

Material published as part of this publication, either on-line or in print, is copyrighted by the Informing Science Institute. Permission to make digital or paper copy of part or all of these works for personal or classroom use is granted without fee provided that the copies are not made or distributed for profit or commercial advantage AND that copies 1) bear this notice in full and 2) give the full citation on the first page. It is permissible to abstract these works so long as credit is given. To copy in all other cases or to republish or to post on a server or to redistribute to lists requires specific permission and payment of a fee. Contact HPublisher@InformingScience.orgH to request redistribution permission.
However, subsequent reports such as the 2002 Young People and ICT (British Educational Communications and Technology Agency [BECTA], 2003) took this view further, arguing that as ICT has become increasingly important for learning, pupils of low social status risk being put at a significant disadvantage when compared to those of higher social status. The latter are more able to take 
advantage of technology at home, by purchasing and using ICT equipment to support their education. This inequality, which has become known as the Digital Divide, is defined by Livingstone \& Helper (2007, p.672) as divisions "within and across societies according to those that have access to digital technologies (including the internet) and those that do not." Something, which Muir \& Oppenheim (2002) argue, is an important global issue that needs addressing at both the national and international level.

In 2005, the Harnessing Technology: Transforming Learning and Children's Services Report (Department for Education and Skills [DfES], 2005) highlighted the continued and growing importance of ICT in supporting children's learning. This report featured a case study on the Digital Divide for Broad Screen High School in Liverpool, where the majority of pupils did not have access to computers at home. Action was taken by the school (with the help of the e-Learning Foundation) to raise sponsorship and offer laptops to pupils, so they could take one home on a rotating basis. Soon after, the school reported more parents were spending time at home using the laptops with their children; attendance of those pupils increased. This case study, although not the first to make reference to the Digital Divide, did again emphasise the barriers and benefits technology has to offer educational provision.

\section{Bridging the Divide}

Although attempts to bridge the Digital Divide have varied from country to country, Warschauer (2003, p.6) suggests that a common method of bridging this divide has been to more narrowly focus on hardware and software provision (so neglecting other factors such as human and social resources). Muir \& Oppenheim (2002) argue it is likely that in many countries universal access programmes aimed to bridge the Digital Divide are in fact encompassed within other initiatives. Noting this, Pateman (1999) draws attention to the use of public libraries in Finland, Sweden, Denmark, and Ireland to bridge the Digital Divide. In Australia, the government chose to offer a range of methods to bridge the Digital Divide, such as investment in community access facilities and training, while for secondary schools it has recently presented The National Secondary School Computer Fund. This aims to achieve one to one computer to student ratio, for years 9 to 12, by the end of 2011 (Department of Education, Employment and Workplace Relations [DEEWR], 2011). In Canada, the Computers for Schools initiative relied on governments for donations of surplus computer equipment and software to schools and libraries, as well as businesses and individuals (Muir \& Oppenheim, 2002). While in the USA the Clinton Administration presented a Presidential memorandum to encourage all departments and agencies to provide their support in bridging the Digital Divide and, more specifically, to connect all schools to the internet (Gunkel, 2003).

In Britain, in order to bridge the Digital Divide, Gordon Brown announced in 2006 (McCall, 2008) further increases in ICT provision, specifically in terms of a programme to provide laptops and connectivity to the poorest members of society. Subsequently, the Computers for Pupils (CfP) programme was formed with a budget of $£ 50$ million (later increased to $£ 60$ million to include connectivity), which unlike other countries' universal access programmes, was specifically aimed at helping the most disadvantaged Key Stage (KS) 3 \& 4 (the stage of schooling for pupils in England and Wales: 11-14 years old for KS3 and 14-16 years old for KS4) children to have access to a new computer in their home. The CfP Guidance Pack v3.0 (BECTA, 2008a, p.4) outlines that the Computers for Pupils initiative will help:

- "Give these pupils the same learning opportunities as their peers.

- Provide the conditions that can contribute towards raising overall educational achievement, narrowing the attainment gap and supporting progress towards school targets. 
- Support personalised learning by providing access to ICT whenever and wherever is most appropriate for learning.

- Encourage the development of ICT skills appropriate to the 21st century for the pupils and their families."

This two year programme (initially managed by DfES although transferred to the British Educational Communications and Technology Agency (BECTA) in January 2007) allocated funding, along with help and advice with regards to the scheme, to local authorities (LA), specifically to those LA's identified as having eligible schools and pupils based on the $10 \%$ of most deprived areas in England (BECTA, 2008a).

\section{Birmingham's Bridge}

One such LA identified was Birmingham, which in partnership with the Birmingham e-Learning Foundation (a registered charity formed in 2002 to significantly increase access to technology for education) and the Building Schools for the Future (BSF) programme, received approximately $10 \%$ of the million pound national allocation of funds (McCall, 2008). Despite being in receipt of funding and support, after one year Ian McCall, the Head of the Birmingham e-Learning Foundation, raised questions. These questions, in his Brief on Birmingham's Universal Home Access (UHA) programme (McCall, 2008, p.1), are shown below (bold only) and elaborated on:

- "How does the programme fit into Teaching and Learning?" By targeting the most disadvantaged pupils in the school the process becomes social rather than educational.

- "How does the school support the students?" What provisions are in place to support the programme and students in schools, as no funding has been provided for this aspect of the programme?

- "What if they get lost or stolen/abused?" Who supports the continued maintenance or replacement of the laptops in such cases of abuse or theft?

- "It's not enough money to make a real difference!" With $£ 400$ provided for the laptop and software, and $£ 100$ for one year's connectivity, who provides the continued funding for connectivity and issues with ageing equipment?

- "What about Learning Platforms, BSF and other initiatives?" Who supports the use of laptops with school systems such as learning platforms and other virtual learning environments that facilitate electronic learning, both in and out of the classroom?

With the above issues identified in Birmingham, the decision by its council, in the beginning of 2007, was to move to the UHA programme within the constraints of the CfP grant. This programme stretches the funding using charitable donations; so instead of targeting the most economically deprived children in the school, the target was to provide laptops to all of Key Stage 3 schools students, beginning with year 8 and 9 followed by year 7 . Inclusiveness and sustainability of the laptops would then continue to be targeted by charitable funds and parental contributions.

In January 2008, Gordon Brown extended this initiative when he announced a further $£ 30$ million (taking the combined total to $£ 90$ million), to build on the CfP with the Access to Technology at Home or Home Access (HA) programme. The vision for home access, as set out by Jim Knight, the then Minister of State for Schools and Learners, is "to ensure that all pupils aged 5-19 in state maintained education in England have the opportunity to have access to computers and internet connectivity for education... at home" (BECTA, 2008b). With the pilot programme already con- 
cluded in Oldham and Suffolk, it was the intention to roll out the scheme across England from late autumn 2009.

Therefore, with the continued importance of the CfP programme and its current extension as the HA programme, it was the aim of this paper to explore the implementation of the Birmingham City Council completed CfP and UHA programme upon a year 9 cohort in one Birmingham school. The decision by Birmingham to adopt the UHA may give insight into the soon to be rolled out HA programme. As the UHA is an extension of the CfP programme, for the purpose of this paper they both are referred to as CfP.

\section{The Case Study}

The school under investigation was a state secondary school (with $44 \%$ of students on free school meals, well above the local authority average of $35 \%$ ), which had adopted the CfP programme by choosing to provide pupils with HP 2133 Mini Note machines. The machines came installed with various pieces of software including the Microsoft Vista Operating System and Microsoft Office 2007 Enterprise. To bridge the funding, parents were asked to donate $£ 5$ per month over 3 years or the lump sum of $£ 180$; at the end of this period, the laptop would become the property of the parent. The laptops came with 1 year hardware warranty and 2 years software warranty. However, this was basic and did not cover accidental damage. Issues and problems with the laptops were reported directly to the laptop supplier Research Machines (RM), as specified in the contract, which was signed by parents, pupil, and a school representative. This cost did not cover connectivity to the internet, although this was to be a future issue, one which has been identified by McCall (2008) in the Brief on Birmingham UHA programme.

\section{The Study}

\section{Aim}

The aim of this case study research was to evaluate the implementation of the Computers for Pupils programme upon a year 9 cohort in a Birmingham School. Although a case study approach may have its advantages and disadvantages, Levy (2008) argues that they are of particular use in measuring perception and can judge in detail the impact of one case that may then be generalised to other similar cases. Therefore, this case study approach was useful in judging the perceptions of the CfP's programme implementation by pupils and teachers and may be used for other similar state secondary schools wishing to implement the CfP's programme. In this study, the definition used for judging implementation effectiveness was the desired result of the programme, which is perhaps best explained by TeacherNet, a site developed by the Department for Children, Schools and Families (DCSF) who developed the programme. TeacherNet (2008) states that it is a programme "to help some of the most disadvantaged secondary children improve their education and life skills by putting a computer into their home." To address the effectiveness of the implementation of the programme, this study measured teacher and pupil perceptions of the programme in terms of impact and improvement upon education and, more specifically, support for learning. This is in line with Herold \& Danolo (2009) who argue that pupils and not just teachers should be involved in research on issues that directly affect them. Therefore pupil and teacher perceptions of the educational impact were central indicators of success. Boettcher \& Cobb (2006) say that subjective perceptions of success are important indicators, and thus one cannot hope to judge the CfP's success without judging how those that are part of it have perceived it. It was not the aim of this research to investigate the impact of the implementation of the CfP programme upon life skills, although this is noted as a recommendation for further research. 


\section{Method}

Two methods were employed to examine the CfP's implementation. Both measured perceptions of the Computers for Pupils programme's support for learning in terms of laptop use, laptop software, laptop hardware, problems, support, and overall conclusions. The methods were as follows:

1. A questionnaire was conducted to examine how pupils perceived the Computers for Pupils programme had supported their learning.

2. A group interview of the school's ICT teachers was conducted to explore their perceptions of the programme's support for pupil learning.

These two methods allowed for effectiveness of the implementation of the programme to be judged by two different but complementary methods that allowed for triangulation. This is something Denscombe (1998) notes researchers should be encouraged to do, as they result in a stronger research design and contribute to more valid and reliable findings. Bowen (2005) supports this by arguing triangulation enhances the rigour of one's research. This study is aware that the effectiveness of triangulation is reduced if the research was not clearly focused (Corner, 1990).

The first method deployed was a pupil evaluation of the CfP programme through a questionnaire. The questions were based on pupil perceptions of the effectiveness of the programme in supporting their learning in terms of laptop use, laptop software, laptop hardware, problems, support, and overall conclusions (see the Appendix for the full questionnaire). The questionnaire, which was developed specifically for this research, was administered via the schools Virtual Learning Environment (VLE), to the year 9 pupils who adopted the scheme. The decision to use the VLE has two primary advantages: first, layout changes could made more easily and instantly as changes would be computerised; and second, data analysis was swifter as it addresses any issues of data collection and processing (Toepoel, Vis, Das, \& Soest, 2008). A total of 46 out of the $58 \mathrm{CfP}$ pupils responded to the questionnaire (79\%), which was completed electronically by logging on to the school VLE and entering in answers to the displayed questions. All 46 questionnaires were usable and extended absence or illness was the reason the remainder did not respond.

The second method, a group interview, was designed to explore the year 9 ICT teachers' perceptions of the programme's influence upon supporting pupil learning. A primary advantage of interviews is that they offer the opportunity for participant's responses to be probed, which can result in increased depth on the issues, as the researcher gains potentially valuable insights from a small number of 'key informants' (Denscombe 1998). This was particularly useful as the ICT department consists of four teachers who could be questioned on the CfP programme. The structure of the interview was semi-structured. Instead of using a series of questions, a series of topics or issues that the interviewer wants to address can be covered in any order, depending on the flow of conversation (Hunt \& McHale, 2007). Consequently, the interviewee has flexibility to speak on the issues raised, and so more emphasis is placed on the interviewee elaborating points of interest (Denscombe, 1998). The series of issues were based (as in the questionnaire) on perceptions of the effectiveness of the programme on support for learning in terms of laptop use, laptop software, laptop hardware, problems, support, and overall conclusions. This allowed for results of the questionnaire and interview to be combined for comparative analysis and evaluation, so allowing themes to be identified and conclusions to be drawn on the future implementation of the programme. The extraction of themes was facilitated by recording the audio of the interview and then later transcribing it: a technique that can be important in getting close to the qualitative data that the interview format provides (Denscombe, 1998). Since the interview was a group one, it offered the advantage of revealing consensus views, which generated richer responses by allowing participants to challenge or confirm each other's responses (Lewis, 1992). 


\section{Results, Discussion, and Recommendations}

In this section pertinent answers from the pupils are discussed (See the Appendix for full questionnaire responses.) and, where possible, integrated with relevant responses from the ICT teachers. Four themes were identified: laptop use and support; provision of connectivity; decisions on software and hardware; and technical support and repair. These themes have then allowed for conclusions to be drawn about the future implementation of the programme.

\section{Theme 1 - Laptop Use and Support}

As noted on the CfP Guidance v3.0 (BECTA, 2008a), a key aim of the CfP initiative is to contribute to raising educational achievement. However, the pupil questionnaire established that many pupils $(43 \%)$ were primarily using the laptops for leisure rather than for educational purposes. Support for the view of non-educational based laptop use was demonstrated by the ICT teachers' perceptions, who judged the impact of the CfP programme to be low, based on verbal feedback from CfP pupils on laptop use. One explanation for this may be due to the ICT teachers being unfamiliar with those pupils who had accepted the scheme. Thus, if the ICT teachers were aware of those pupils on the programme they could have sought targeted responses on laptop use. The ICT teachers' lack of knowledge of the programme appears to be due to responsibility of the programme remaining with the schools Senior Leadership Team (SLT). One member of the ICT staff (who was also a member of SLT), who had a greater level of knowledge and involvement in the deployment of the programme than the other ICT staff, provided evidence for this. This member of staff stated that he had "actually sat in the hall as parents have come in to buy the computers and helped them to fill in the payment agreement forms." The lack of involvement of the ICT teachers may be a factor that explains why there is no laptop support in ICT lessons and why the use of the laptop has not been educationally- driven. This echoes McCall (2008) who questions how the CfP laptops are supporting learning both in and out of the classroom. McCall anticipated that Birmingham City Council's decision to move the CfP programme to the UHA programme, and provide laptops to all students in the year group, would address inclusivity issues and, therefore, make providing laptop support easier. However, it was found that the decision to move to the UHA has not solved problems in terms of support with learning in this school, or influenced laptop use by pupils, primarily because the provisions of support were not outlined or included by the UHA programme. A recommendation would therefore be to include a mandate outlining the required school support for laptops by the UHA programme. This would require dedicated funding, specifically in terms of school staff involvement, as well as making it clear to the leadership team of a school how the programme should be facilitated. However, it is necessary to note that it is not considered feasible to expect the schools leadership team or ICT teachers to facilitate laptop use without the necessary time and resources (Butt \& Lance, 2005). For instance, Newman \& Mathews (1999) noted that limited training, communication, or an overburdening of resources could be a factor that has a detrimental effect upon workplace policies. Desimone (2006), who found that barriers to the successful implementation of education policy and programmes often included issues of unclear guidance and resources, further supports this. By outlining clear guidance and responsibility to all within the school, along with funding for its implementation, such barriers may be reduced.

\section{Theme 2- Provision of Connectivity}

To enhance the pupils' education, it was decided that connectivity was to be provided with the CfP programme. Despite a sum of $£ 10$ million being included for connectivity, and despite further funds for the UHA from charitable donations, (McCall (2008) noted that $£ 100$ per pupil was being provided for one year's connectivity), no connectivity had been provided for the laptops to the school. However, 93\% of pupils reported having access to the internet at home, and of those 
$72 \%$ noted primarily using the internet for social networking rather than for educational purposes. This shows that the funding of connectivity has not reached its intended target and has either not been used or has been reallocated. Further to this, Livingstone \& Helsper (2007) argue that the benefits of what the internet actually brings have yet to be established; merely providing internet access is insufficient to ensuring equality of opportunity. It is therefore recommended that until there is sufficient and reliable research on the benefits of social networking sites to either education or life skills the funding of connectivity should be reallocated, for instance, to facilitate school and staff involvement in the laptop deployment in school.

\section{Theme 3 - Decisions on Software and Hardware}

While most (80\%) pupils reported having all or most of the software needed to help them with their school work and homework, some (9\%) reported not having a Microsoft program such as Word or Publisher; this goes against the specifications provided by Research Machines (RM). The issue with provision of software for laptop use was highlighted further by the ICT teachers, who, although lacking knowledge on the programme, were aware of incompatibility issues between school and laptop systems, specifically in terms of transferring Microsoft Office documents. The SLT ICT teacher, who had the greater level of knowledge on the programme, supported this. He noted "issues with compatibility of software" and also issues with software changing quickly, which the school could update but "families generally by and large won't or don't necessarily know how." Further, many of the ICT teachers felt that there had been only little thought put into the choices of software for the laptops. Consequently, this paper recommends that choice of software for laptops be either decided upon a school-by-school basis or upon a uniform Virtual Learning Environment basis, which would facilitate laptop use (specifically in terms of file transfer) both in and outside of school. Orsini-Jones \& Jones (2007) note that Virtual Learning Environments have many positive effects upon learning, such as increasing a student's motivation and understanding of the subject matter.

The results revealed that $83 \%$ of CfP pupils stated that they had all or most of the hardware needed to complete their schoolwork or homework, while $52 \%$ said that a CD/DVD drive would be most useful. The importance of such is highlighted by Wishart (1999), who indicates that CDROM educational software is highly valued and can have a positive impact upon pupil learning. Hillis \& Munro (2005) advocate the merits of educational CD-ROM software, although they do warn of the dangers of over emphasising its values. This research recommends that further deployment of new models of laptops in schools should include a CD/DVD drive. Further support for the installation of a CD/DVD drive is provided by the Home-School Agreement that states, "It is important that you back up work and data stored on the laptop on a regular basis (e.g. by making CD copies)" (Birmingham e-Learning Foundation, 2008, p.2) something that would be difficult without the drive or the provision of a USB memory stick. However, the decreasing price of laptops and hardware means that later it may be financially feasible to include CD/DVD drives under the scheme.

\section{Theme 4 - Technical Support and Repair}

Not including accidental damage, $63 \%$ of CfP pupils indicated that they had experienced problems with their laptop's hardware or software. Support from both the school and manufacturer was judged as average by the majority of respondents ( $46 \%$ for the school and $57 \%$ for the manufacturer) and some problems were identified. Umrani \& Ghadially (2003) note the importance of technical support in repair and maintenance and suggest that lack of hardware and software support can be a key barrier for any computer use. In terms of correcting problems with hardware and software, ICT teachers reported that many pupils would bring their laptops to the school's ICT technicians for repair, although the technicians did not considered this their responsibility. 
The SLT ICT teacher reported that many families thought the "school was responsible" for the maintenance and repair of the laptops, when in fact such responsibility lies with the manufacturer. This misconception had led to a break down in relationships between school and families. A reason for this misunderstanding may lie primarily with the CfP Home-School Agreement (Birmingham e-Learning Foundation, 2008) that is signed between school and family. The contract states that "the laptop remains the property of the school" and there may be occasions when the laptops need to be "returned to school and/or RM for repair." Further to this, the school signs the HomeSchool Agreement to indicate their intention to provide a laptop to the family. Thus, the language of the agreement does not make it clear just where responsibility for laptop repair actually lies. Therefore, this paper recommends that the wording of the Home-School Agreement be modified to indicate where responsibility of the laptop actually lies. Indeed, one recommendation from the ICT teachers was for RM to provide funding to the school's technicians and have them be responsible for laptop repair. As laptops are distributed through schools, this may be a credible solution. Sirgy et al. (2008), who show that local technical support is the key to consumer satisfaction, support this.

Another point of discussion is the life of laptop support, as mentioned by the SLT ICT teacher who argued that laptop software often suffers from becoming obsolete. A fair question is, "Is it fair to provide a laptop to those families that financially struggle to afford them and then not continue to provide support for the laptop during the life of the child at school?" This is a particularly pertinent question as the aim of the CfP, as announced by Gordon Brown in 2006 (McCall, 2008), is to bridge the Digital Divide by providing connectivity to the poorest members of society. Therefore, this paper recommends that support should last for the duration of the child in school. Livingstone \& Helsper (2007) agree and argue that bridging the Digital Divide requires continual rather than one off investments. This recommendation may be rejected due to funding issues. Nonetheless, this paper suggests that perhaps laptops should not have been offered to everyone in the year group and instead distribution should have been more focused, for instance those pupils on free school meals. McCall (2008) implies that that the targeting of whole year groups was so the programme has educational benefits and not just social. That said, without taking advantage of the laptops both in and out of school, the programme does not fully offer such educational benefits.

\section{Conclusion}

In conclusion, the above findings and recommendations for improvement to the implementation of the CfP programme, and its extension the UHA programme, are summarised below:

\begin{tabular}{|l|l|}
\hline Results & Recommendations \\
\hline $\begin{array}{l}\text { ICT teachers were not informed of the pupils on } \\
\text { the CfP programme and many pupils are primar- } \\
\text { ily using the laptops for leisure rather than for } \\
\text { education purposes. The lack of involvement of } \\
\text { the ICT teachers may explain why there is no } \\
\text { laptop support in ICT lessons and why the use of } \\
\text { laptops has not been educationally based. }\end{array}$ & $\begin{array}{l}\text { The nature of school support for laptops } \\
\text { offered by the CfP programme should in- } \\
\text { clude dedicated funding. Specifically, in } \\
\text { terms of school staff involvement; it should } \\
\text { be made clear to the school leadership team } \\
\text { how the programme should be facilitated. }\end{array}$ \\
\hline $\begin{array}{l}\text { The funding of connectivity has not reached its } \\
\text { intended target and has either not been used or } \\
\text { has been reallocated elsewhere. }\end{array}$ & $\begin{array}{l}\text { The funding of connectivity should be real- } \\
\text { located - for instance to facilitate school } \\
\text { and staff involvement in the laptop de- } \\
\text { ployment in a school. }\end{array}$ \\
\hline
\end{tabular}




\begin{tabular}{|c|c|}
\hline Results & Recommendations \\
\hline $\begin{array}{l}\text { A small number of pupils' laptops do not con- } \\
\text { tain all the software as specified by RM; the ICT } \\
\text { teachers are aware of compatibility issues be- } \\
\text { tween school and laptop systems. Many of the } \\
\text { ICT teachers felt that there had been little } \\
\text { thought put into the choices of software for the } \\
\text { laptops. }\end{array}$ & $\begin{array}{l}\text { Choice of software should be decided upon } \\
\text { a school-by-school basis or a uniform Vir- } \\
\text { tual Learning Environment setup to facili- } \\
\text { tate laptop use (specifically in terms of file } \\
\text { transfer) both in and outside school. }\end{array}$ \\
\hline $\begin{array}{l}\text { Over half of pupils noted that a CD/DVD drive } \\
\text { would most help them to complete their school- } \\
\text { work or homework. The lack of CD/DVD drive } \\
\text { contradicts the Home-School agreement which } \\
\text { asks pupils to backup work (for instance on a } \\
\text { CD). }\end{array}$ & $\begin{array}{l}\text { Deployment of new models of laptops in } \\
\text { schools should include a CD/DVD drive for } \\
\text { the purpose of data backup, as outlined in } \\
\text { the CfP. }\end{array}$ \\
\hline $\begin{array}{l}\text { Not including accidental damage, almost two } \\
\text { thirds of CfP pupils indicated that they experi- } \\
\text { enced problems with the hardware or software } \\
\text { on their laptop. In terms of correcting problems, } \\
\text { ICT teachers reported that many would bring } \\
\text { their laptops to the school's ICT technicians to } \\
\text { be repaired, when this was not considered to fall } \\
\text { within their responsibility. A reason for this may } \\
\text { lie with the CfP Home-School Agreement that } \\
\text { indicates that laptops may need to be returned to } \\
\text { school and/or RM for repair. }\end{array}$ & $\begin{array}{l}\text { Home-School Agreement should be modi- } \\
\text { fied to indicate where responsibility of the } \\
\text { laptops lies, specifically in terms of repair. } \\
\text { Due to the distribution of laptops being } \\
\text { through schools, funding could be supplied } \\
\text { to the school's technicians in return for re- } \\
\text { sponsibility for laptop repair. }\end{array}$ \\
\hline $\begin{array}{l}\text { Laptop support does not last for the duration of } \\
\text { the child in school and laptop software often } \\
\text { suffers from becoming obsolete. }\end{array}$ & $\begin{array}{l}\text { Laptop support should last for the duration } \\
\text { of the child in school. Some funding might } \\
\text { be achieved for this by reinitiating laptop } \\
\text { provision through a more focused approach } \\
\text { instead of across year group }\end{array}$ \\
\hline
\end{tabular}

\section{Further Research}

This study found that many pupils are using the laptops provided by the CfP programme to access social networking sites. Although this does not help in determining the impact of the programme in supporting learning, as measured by this study, accessing social networking sites may have other constructive effects such as positively affecting life skills. Indeed, Alwell \& Cobb (2009) argue communication and social skills can be incorporated into a category of life skills. Support for this is also provided by Morgan (2010) who argues that social networking sites may have an impact in increasing social competence in students, particularly those with emotional and behavioural disorders.

Many of the school's ICT teachers referred to the role of the school's technicians in facilitating the CfP programme, such as dealing with laptop repair. Lackie (1999), who noted that effective communication is required across all constituencies in schools, particularly technical support staff, supports the importance of involving the school's ICT technicians in introducing new technologies. Therefore, in order to understand fully the method of laptop dispersal, as well as issues of repair, it would be necessary to conduct interviews with the school's technicians. 
This research examined the implementation of the CfP programme, and its extension the UHA, in one Birmingham school, but in order to verify the findings of this research the study must be expanded. The benefits of expanding a research study to include a larger and broader sample size is argued by Slavin \& Smith (2009) who note that smaller samples often increase effect size and can undermine validity. It is therefore necessary to extend this research to include a number of schools in Birmingham. It would also be useful to research the deployment of the HA programme across different Local Authorities in England to measure the impact of that programme and measure its effectiveness compared to the CfP and UHA programmes.

In summary the recommendation for further research are offered below:

- Research should be conducted to measure the impact the implementation of the CfP programme has upon pupils' life skills.

- The impact of social networking sites upon children should be measured with particular focus upon education and life skills.

- Further interviews should be conducted with school technicians to examine their role in the CfP.

- The research should be expanded to measure the impact of the implementation of the Universal Home Access programme upon different schools in Birmingham

- Further research should be conducted on the deployment of the Home Access programme across different Local Authorities.

\section{References}

Alwell, M., \& Cobb, B. (2009). Functional life skills curricular interventions for youth with disabilities: A systematic review. Career Development for Exceptional Individuals, 32(2), 82-93.

Birmingham e-Learning Foundation. (2008). Home-School Agreement. Birmingham: Author.

Boettcher, W. A., III, \& Cobb, M. D. (2006). Echoes of Vietnam? Casualty framing and public perceptions of success and failure in Iraq. Journal of Conflict Resolution, 50, 831-854.

Bowen, G. A. (2005). Preparing a qualitative research-based dissertation: Lessons learned. The Qualitative Report, 10(2), 208-222.

British Educational Communications and Technology Agency. (2003). Young people and ICT 2002. Coventry: Author.

British Educational Communications and Technology Agency. (2008a). Computer for Pupils (CfP) Guidance v3.0. London: Author.

British Educational Communications and Technology Agency. (2008b). Home access. Retrieved from http://schools.becta.org.uk/index.php?section $=0$ oe\&catcode $=$ ss es hom $02 \&$ rid $=15871$

Butt, G., \& Lance, A. (2005). Secondary teacher workload and job satisfaction: Do successful strategies for change exist? Educational Management Administration \& Leadership, 33(4), 401-422.

Corner, J. (1990). Qualitative versus qualitative research methods: Is there a way forward? Journal of Advance Nursing, 6(2), 718-727.

Denscombe, M. (1998). The good research guide: For small-scale social research projects. Buckingham: Open University Press.

Department for Education and Skills. (2005). The harnessing technology: Transforming learning and children's services report. London: Author.

Department of Education, Employment and Workplace Relations. (2011). National secondary school computer fund overview. Retrieved from 
http://www.deewr.gov.au/SCHOOLING/DIGITALEDUCATIONREVOLUTION/COMPUTERFUND Pages/NationalSecondarySchoolComputerFundOverview.aspx

Desimone, L. M. (2006). Consider the source: Response difference among teachers, principals, and districts on survey questions about their education policy environment. Educational Policy, 20(4), 640-676.

Gunkel, D. J. (2003). Second thoughts: Towards a critique of the digital divide. New Media and Society, 5, 499-522.

Herold, F., \& Dandolo, J (2009). Including visually impaired students in physical education lessons: A case study. British Journal of Visual Impairment, 27, 75-84.

Hillis, P. \& Munro, B. (2005). ICT in history education - Scotland and Europe. Social Science Computer Review, 23(2), 190-205.

Hunt, N. \& McHale, S. (2007). A practical guide to the e-mail interview. Qualitative Health Research, 17, $1415-1421$.

Lackie, P. (1999). Implementing technical innovations in the curriculum: Guidelines for faculty and technical support staff. Social Science Computer Review, 17(2), 189-195.

Lewis, A. (1992). Group child interviews as a research tool. British Educational Research Journal, 18, 413-432.

Levy, J. S. (2008). Case studies: Types, designs, and logic of inference. Conflict Management and Peace Science, 25, 1-18.

Livingstone, S., \& Helsper, E. (2007). Gradations in digital inclusion: Children, young people and the digital divide. New Media and Society, 9(4), 671-696.

McCall, I. (2008). Brief on Birmingham UHA programme. Birmingham: Birmingham e-Learning Foundation.

Morgan, J. J. (2010). Social networking sites teaching appropriate social competence to students with emotional and behavioural disorders. Intervention in School and Clinic, 45(3), 147-157.

Muir, A., \& Oppenheim, C. (2002). National information policy developments worldwide II: Universal access - addressing the digital divide. Journal of Information Science, 28, 263-73.

Newman, M. A., \& Matthews, K. (1999). Federal family-friendly work place policies: Barriers to effective implementation. Review of Public Personal Administration, 19, 34-48.

Orsini-Jones, M., \& Jones, D. (2007). Supporting collaborative grammar learning via a virtual learning environment. Arts and Humanities in Higher Education, 6, 90-106.

Pateman, J. (1999). Social exclusion. Journal of Information Science, 25, 445-463.

Sirgy, J. M., Lee, D-J., Grzeskowiak, S., Chebat, J-C., Johar, J. S., Hermann, A., . . Montana, J. (2008). An extension and further validation of a community-based consumer well-being measure. Journal of Macromarketing, 28(3), 243-257.

Slavin, R., \& Smith, D. (2009). The relationship between sample sizes and effect sizes in systematic reviews in education. Educational Evaluation and Policy Analysis, 31(4), 500-506.

Stevenson, D. (1997). Information and communications technology in UK schools: An independent inquiry. London: The Independent ICT in Schools Commission.

TeacherNet. (2008) Computers for pupils. Retrieved from http://www.teachernet.gov.uk/wholeschool/ictis/computers_for_pupils

Toepoel, V., Vis, C., Das, M., \& Soest, A. V. (2008). Design of web questionnaires: An informationprocessing perspective for the effect of response categories. Sociology Methods \& Research, 37, 371392.

Umrani, F., \& Ghadially, R. (2003). Empowering women through ICT education: Facilitating computer adoption. Gender Technology and Development, 7(3), 359-77. 
Warschauer, M. (2003) Technology and social inclusion: Rethinking the digital divide. Cambridge, MA: MIT Press.

Wishart, J. M. (1999). CD-ROM in schools: Librarians' and teachers' views. Journal of Librarianship and Information Science, 31(3), 168-73.

\section{Appendix}

\section{Pupil Questionnaire and Answers}

\begin{tabular}{|c|c|c|c|c|c|c|c|c|c|c|c|}
\hline QUESTIONS & \multicolumn{11}{|c|}{ ANSWERS } \\
\hline $\begin{array}{l}\text { Did you receive a laptop } \\
\text { from the Computers for } \\
\text { Pupils programme? }\end{array}$ & \multicolumn{5}{|l|}{$\begin{array}{l}\text { Yes } \\
46(100 \%)\end{array}$} & \multicolumn{6}{|l|}{$\begin{array}{l}\text { No } \\
0(0 \%)\end{array}$} \\
\hline \multicolumn{12}{|l|}{ LAPTOP USE } \\
\hline $\begin{array}{l}\text { Approximately how many } \\
\text { hours a week do you use } \\
\text { your laptop? }\end{array}$ & $\begin{array}{l}0 \\
4(9 \%)\end{array}$ & \multicolumn{2}{|c|}{$\begin{array}{l}1-5 \\
16(35 \%)\end{array}$} & \multicolumn{2}{|c|}{$\begin{array}{l}6-10 \\
9(20 \%)\end{array}$} & \multicolumn{3}{|c|}{$\begin{array}{l}11-15 \\
8(17 \%)\end{array}$} & \multicolumn{3}{|c|}{$\begin{array}{l}15+ \\
9(20 \%)\end{array}$} \\
\hline $\begin{array}{l}\text { Not including the internet, } \\
\text { what do you mainly use } \\
\text { your laptop for? }\end{array}$ & \multicolumn{3}{|c|}{$\begin{array}{l}\text { Education e.g. school } \\
\text { work or homework } \\
21(46 \%)\end{array}$} & \multicolumn{4}{|c|}{$\begin{array}{l}\text { Entertainment e.g. playing } \\
\text { games or watching films } \\
20(43 \%)\end{array}$} & \multicolumn{4}{|c|}{$\begin{array}{l}\text { Other } \\
5(11 \%)\end{array}$} \\
\hline $\begin{array}{l}\text { If you chose other please } \\
\text { say what you mainly use } \\
\text { your laptop for: }\end{array}$ & \multicolumn{11}{|c|}{$\begin{array}{l}\text { - "I use it to do school work and for entertainment" } \\
\text { - "Homework and games" } \\
\text { - "Educational and entertainment" } \\
\text { - "Msn, Facebook and Google" } \\
\end{array}$} \\
\hline $\begin{array}{l}\text { Is your laptop connected to } \\
\text { the internet? }\end{array}$ & \multicolumn{5}{|c|}{\begin{tabular}{l|l|l} 
Yes & \\
$43(93 \%)$ &
\end{tabular}} & \multicolumn{6}{|c|}{$\begin{array}{l}\text { No } \\
3(7 \%)\end{array}$} \\
\hline $\begin{array}{l}\text { If yes, what do you mainly } \\
\text { use the internet for? }\end{array}$ & $\begin{array}{l}\text { Education } \\
\text { e.g. school } \\
\text { work or } \\
\text { homework } \\
5(12 \%)\end{array}$ & \multicolumn{2}{|c|}{$\begin{array}{l}\text { Entertain- } \\
\text { ment e.g. } \\
\text { playing } \\
\text { games or } \\
\text { watching } \\
\text { films } \\
4(9 \%)\end{array}$} & \multicolumn{2}{|c|}{$\begin{array}{l}\text { General } \\
\text { browsing } \\
\text { e.g. news or } \\
\text { information } \\
1(2 \%)\end{array}$} & \multicolumn{2}{|c|}{$\begin{array}{l}\text { Social net- } \\
\text { working } \\
\text { e.g. face- } \\
\text { book or msn } \\
31(72 \%)\end{array}$} & \multicolumn{3}{|c|}{$\begin{array}{l}\text { Shopping } \\
\text { e.g. buying } \\
\text { music, } \\
\text { clothes or } \\
\text { DVDs } \\
0(0 \%)\end{array}$} & $\begin{array}{l}\text { Other } \\
2(5 \%)\end{array}$ \\
\hline $\begin{array}{l}\text { If other, what do you } \\
\text { mainly use the internet for? }\end{array}$ & \multicolumn{11}{|c|}{$\begin{array}{l}\text { - "They use the internet for everything e.g shopping, Facebook, and research" } \\
\text { - "Educational, entertainment, general browsing social and networking" }\end{array}$} \\
\hline \multicolumn{12}{|l|}{ LAPTOP SOFTWARE } \\
\hline $\begin{array}{l}\text { Which of these match your } \\
\text { experience of the software } \\
\text { your laptop comes installed } \\
\text { with? }\end{array}$ & \multicolumn{2}{|c|}{$\begin{array}{l}\text { I have all of the } \\
\text { software I need to } \\
\text { complete my school } \\
\text { work and home- } \\
\text { work } \\
19(41 \%)\end{array}$} & \multicolumn{3}{|c|}{$\begin{array}{l}\text { I have most of the } \\
\text { software I need to } \\
\text { complete my school } \\
\text { work and home- } \\
\text { work } \\
18(39 \%)\end{array}$} & \multicolumn{3}{|c|}{\begin{tabular}{|l} 
I have some of the \\
software I need to \\
complete my school \\
work and home- \\
work \\
$9(20 \%)$
\end{tabular}} & \multicolumn{3}{|c|}{$\begin{array}{l}\text { I have none of the } \\
\text { software I need to } \\
\text { complete my school } \\
\text { work and home- } \\
\text { work } \\
(0 \%)\end{array}$} \\
\hline $\begin{array}{l}\text { If you do not have all the } \\
\text { software you need, which } \\
\text { software would most help } \\
\text { you in your school and } \\
\text { home work? }\end{array}$ & $\begin{array}{l}\text { Editing soft- } \\
\text { ware e.g. Pin- } \\
\text { nacle or Adobe } \\
\text { Premiere } \\
4(15 \%)\end{array}$ & \multicolumn{3}{|c|}{$\begin{array}{l}\text { Image editing } \\
\text { software e.g. } \\
\text { Paint Shop Pro } \\
\text { or Adobe Pho- } \\
\text { toshop } \\
4(15 \%)\end{array}$} & \multicolumn{2}{|c|}{$\begin{array}{l}\text { Sound editing } \\
\text { software e.g. } \\
\text { Audacity } \\
4(15 \%)\end{array}$} & \multicolumn{3}{|c|}{$\begin{array}{l}\text { Web page } \\
\text { design soft- } \\
\text { ware e.g. Mac- } \\
\text { romedia } \\
\text { Dreamweaver } \\
9(33 \%)\end{array}$} & \multicolumn{2}{|c|}{$\begin{array}{l}\text { Other } \\
6(22 \%)\end{array}$} \\
\hline $\begin{array}{l}\text { If you chose other please } \\
\text { say which software: }\end{array}$ & \multicolumn{11}{|c|}{$\begin{array}{l}\text { - "Paintshop Pro, Microsoft Word etc" } \\
\text { - "Editing software, image editing software, sound editing software and Macro- } \\
\text { - } \quad \text { media Dreamweaver" } \\
\text { - "Microsoft PowerPoint, Word" } \\
\text { - "Microsoft Publisher" } \\
\text { "Microsoft Publisher" }\end{array}$} \\
\hline
\end{tabular}




\begin{tabular}{|c|c|c|c|c|c|c|c|c|c|c|}
\hline QUESTIONS & \multicolumn{10}{|c|}{ ANSWERS } \\
\hline \multicolumn{11}{|l|}{ LAPTOP HARDWARE } \\
\hline $\begin{array}{l}\text { Which of these match your } \\
\text { experience of the hardware } \\
\text { your laptop has? }\end{array}$ & \multicolumn{2}{|c|}{$\begin{array}{l}\text { I have all of the } \\
\text { hardware I need to } \\
\text { complete my school } \\
\text { and home work } \\
17(37 \%)\end{array}$} & \multicolumn{3}{|c|}{$\begin{array}{l}\text { I have most of the } \\
\text { hardware I need to } \\
\text { complete my school } \\
\text { and home work } \\
21(46 \%)\end{array}$} & \multicolumn{3}{|c|}{$\begin{array}{l}\text { I have some of the } \\
\text { hardware I need to } \\
\text { complete my school } \\
\text { and home work } \\
8(17 \%)\end{array}$} & \multicolumn{2}{|c|}{$\begin{array}{l}\text { I none of the hard- } \\
\text { ware I need to } \\
\text { complete my school } \\
\text { and home work } \\
0(0 \%)\end{array}$} \\
\hline $\begin{array}{l}\text { If you do not have all the } \\
\text { hardware you need, which } \\
\text { hardware would most help } \\
\text { you in your school and } \\
\text { home work? }\end{array}$ & $\begin{array}{l}\text { CD/DVD } \\
\text { Drive } \\
15(52 \%)\end{array}$ & $\begin{array}{l}\text { Digital } \\
\text { Camer } \\
1(3 \%)\end{array}$ & & & & $\begin{array}{l}\text { Scann } \\
1(3 \%)\end{array}$ & & $\begin{array}{l}\text { Video } \\
\text { Camer } \\
0(0 \%)\end{array}$ & & $\begin{array}{l}\text { Other } \\
4(14 \%)\end{array}$ \\
\hline $\begin{array}{l}\text { If you chose other please } \\
\text { say which hardware: }\end{array}$ & \multicolumn{10}{|c|}{$\begin{array}{l}\quad \text {-I'm not sure" } \\
\text { - "Don't know" } \\
\text { - "CD/DVD drive, video camera, digital camera" } \\
\text { - "Music software and Paint Shop pro" }\end{array}$} \\
\hline \multicolumn{11}{|l|}{ PROBLEMS } \\
\hline $\begin{array}{l}\text { Not including accidental } \\
\text { damage, have you ever } \\
\text { experienced any problems } \\
\text { with the hardware or soft- } \\
\text { ware of your laptop? }\end{array}$ & \multicolumn{5}{|l|}{$\begin{array}{l}\text { Yes } \\
29(63 \%)\end{array}$} & \multicolumn{5}{|c|}{$\begin{array}{l}\text { No } \\
17(37 \%)\end{array}$} \\
\hline $\begin{array}{l}\text { If yes, which of the follow- } \\
\text { ing problems have you } \\
\text { experienced? }\end{array}$ & \multicolumn{2}{|c|}{\begin{tabular}{l|l} 
Software - & Sof \\
error code & syst \\
$4(14 \%)$ & $5(1$ \\
\end{tabular}} & $\begin{array}{l}\text { ftwar } \\
\text { tem } \\
17 \% \\
\end{array}$ & & \multicolumn{2}{|c|}{$\begin{array}{l}\text { Hardware - } \\
\text { faulty battery } \\
10(34 \%)\end{array}$} & \multicolumn{3}{|c|}{$\begin{array}{l}\text { Hardware - } \\
\text { faulty screen } \\
1(3 \%) \\
\end{array}$} & $\begin{array}{l}\text { Other } \\
9(31 \%)\end{array}$ \\
\hline If other please explain: & \multicolumn{10}{|c|}{$\begin{array}{l}\text { - "Motherboard crashed and the charger blew up" } \\
\text { - "My computer keeps crashing before I have chance to load it up properly so I } \\
\text { have to restart it. It is also really slow and not that much memory on it to save } \\
\text { homework or anything you will need to know and have for next lesson in } \\
\text { school." } \\
\text {-It takes its time to load up and also the antivirus thing ran out after } 1 \text { year and } \\
\text { - "Low I have got lots of viruses" } \\
\text { - "Track pad gone and too slow" } \\
\text { - "Hardware - faulty battery and it is really slow" } \\
\text { - "My charger broke it is not good" } \\
\text { - "My charger" } \\
\text { - "I don't know I just gave it to my family member" }\end{array}$} \\
\hline \multicolumn{11}{|c|}{$\begin{array}{llllll} & 0\end{array}$} \\
\hline $\begin{array}{l}\text { If needed, how would you } \\
\text { rate the support you have } \\
\text { received from the school } \\
\text { for your laptop? }\end{array}$ & $\begin{array}{l}\text { Very Good } \\
5(11 \%)\end{array}$ & $\begin{array}{l}\text { Good } \\
10\left(22^{\circ}\right.\end{array}$ & & & & $\begin{array}{l}\text { Poor } \\
4(9 \%)\end{array}$ & & $\begin{array}{l}\text { Very P } \\
5(11 \%\end{array}$ & & $\begin{array}{l}\text { Not Needed } \\
1(2 \%)\end{array}$ \\
\hline $\begin{array}{l}\text { If you have chosen 'poor' } \\
\text { or 'very poor' please ex- } \\
\text { plain: }\end{array}$ & \multicolumn{10}{|c|}{$\begin{array}{l}\text { - "They don't give any help if you tell them your laptop has broken" } \\
\text { - "Because my dad waited for a long time, for the school to get back to him" } \\
\text { - "Because it's too slow and it takes long to load" } \\
\text { - "I had no help I was just told to ring a number" } \\
\text { - "Because they didn't explain anything" } \\
\text { - "School told us to ring HP" } \\
\text { - "I advise is given" } \\
\end{array}$} \\
\hline $\begin{array}{l}\text { If needed, how would you } \\
\text { rate the support you have } \\
\text { received from the manufac- } \\
\text { turer for your laptop? }\end{array}$ & $\begin{array}{l}\text { Very Good } \\
3(7 \%)\end{array}$ & $\begin{array}{l}\text { Good } \\
8(17 \%\end{array}$ & & & & $\begin{array}{l}\text { Poor } \\
5(11 \%\end{array}$ & & $\begin{array}{l}\text { Very P } \\
2(4 \%)\end{array}$ & & \begin{tabular}{|l} 
Not Needed \\
$2(4 \%)$
\end{tabular} \\
\hline
\end{tabular}




\begin{tabular}{|c|c|c|c|c|c|}
\hline QUESTIONS & \multicolumn{5}{|c|}{ ANSWERS } \\
\hline $\begin{array}{l}\text { If you have chosen 'poor' } \\
\text { or 'very poor' please ex- } \\
\text { plain: }\end{array}$ & \multicolumn{5}{|c|}{$\begin{array}{l}\text { - "Because it's too slow" } \\
\text { - "As when I needed them to fix my laptop they didn't fix it properly and I had to } \\
\text { - " } \text { "Whe it to another laptop shop for it to be fixed" } \\
\text { - "They just kept asking to call to different numbers to get it fixed it took a week } \\
\text { - just to get it fixed" } \\
\text {-Because I don't get no support" } \\
\text {-It is very slow" }\end{array}$} \\
\hline \multicolumn{6}{|c|}{ (2) } \\
\hline $\begin{array}{l}\text { Please tick the statement } \\
\text { you agree with most }\end{array}$ & $\begin{array}{l}\text { I am extremely } \\
\text { pleased to have } \\
\text { the laptop to } \\
\text { help me with } \\
\text { my school and } \\
\text { homework } \\
7(15 \%)\end{array}$ & $\begin{array}{l}\text { I am quite } \\
\text { pleased to have } \\
\text { the laptop to } \\
\text { help me with } \\
\text { my school and } \\
\text { homework } \\
22(48 \%)\end{array}$ & $\begin{array}{l}\text { I don't mind } \\
\text { either way } \\
\text { having the } \\
\text { laptop to help } \\
\text { me with my } \\
\text { school and } \\
\text { homework } \\
15(33 \%)\end{array}$ & $\begin{array}{l}\text { I don't really } \\
\text { need the laptop } \\
\text { to help me with } \\
\text { my school and } \\
\text { homework } \\
2(4 \%)\end{array}$ & $\begin{array}{l}\text { I wish I had not } \\
\text { received the } \\
\text { laptop to help } \\
\text { me with my } \\
\text { school and } \\
\text { homework } \\
0(0 \%)\end{array}$ \\
\hline $\begin{array}{l}\text { Is there is anything else you } \\
\text { would like to mention about } \\
\text { the laptop or Computers for } \\
\text { Pupils programme? }\end{array}$ & \multicolumn{5}{|c|}{ 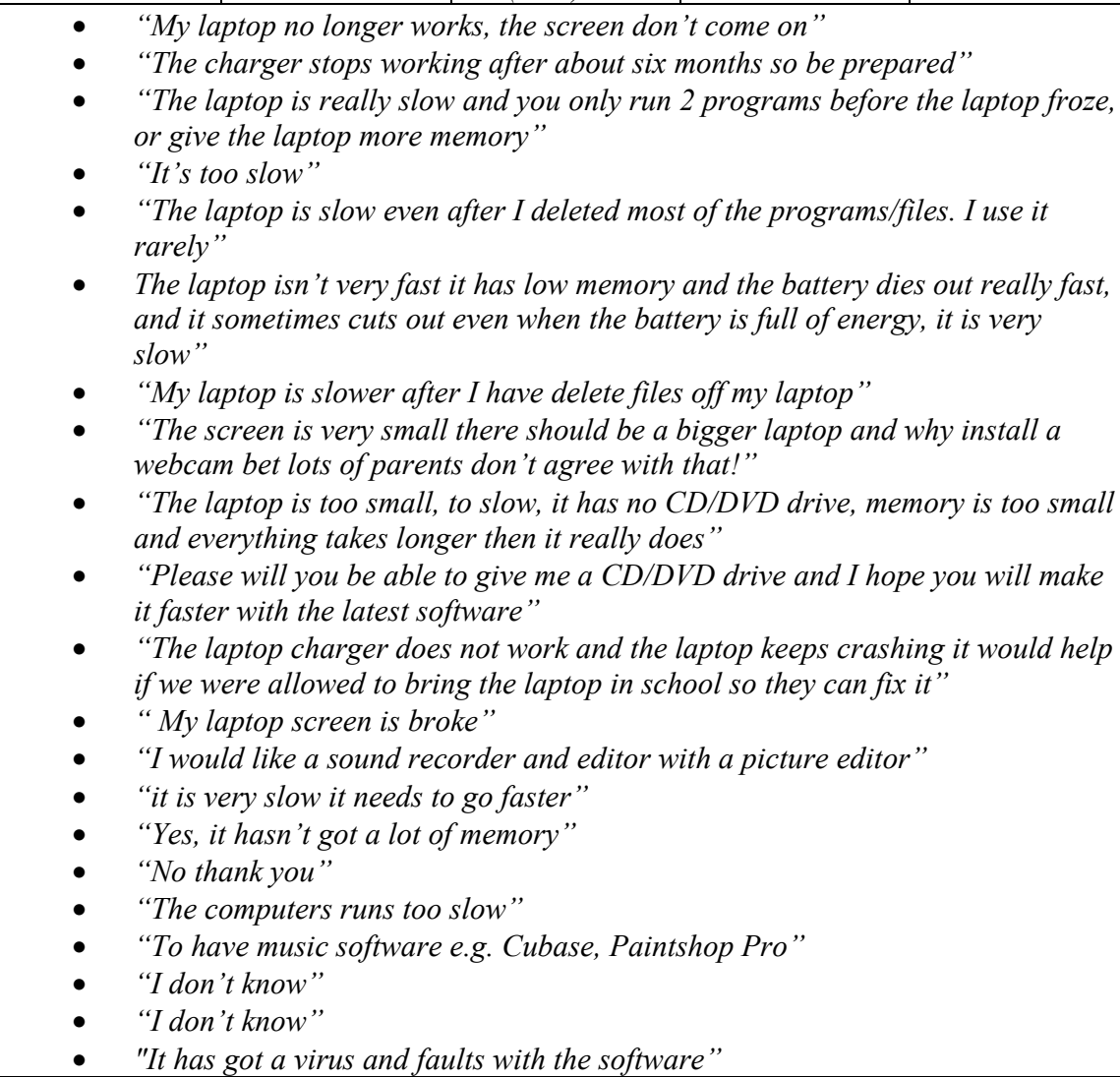 } \\
\hline
\end{tabular}




\section{Biography}

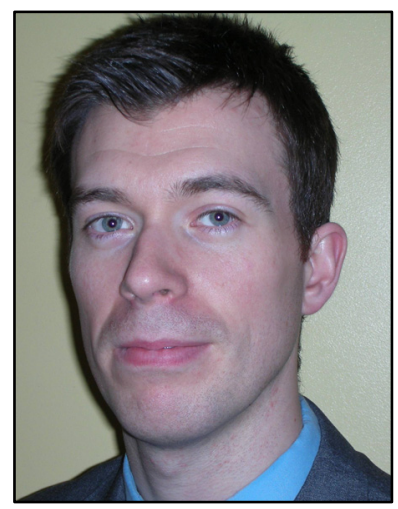

Jonathan Padraig Morris received his BA (Hons.) from the University of Glamorgan, PGCE from University of Worcester, and MA from University College Birmingham. Initially working as an Information Communications Technology (ICT) teacher and lecturer, he is currently the Head of Media Studies at King Edward VI Sheldon Heath Academy. Jonathan's research interests include the implementation of ICT in schools and the culture of academies. 